\title{
Genesis of magnesite deposits in the view of isotope geochemistry
}

\author{
ERICH SCHROLL
}

\begin{abstract}
Institute of Mineralogy and Crystallography, University Vienna, Althanstraße 14, A-1090 Wien, Austria - erich.schroll@univie.ac.at
\end{abstract}

(Received November 2002 Accepted December 2002)

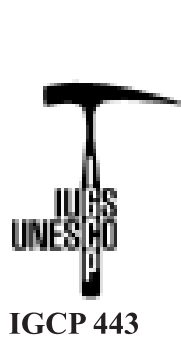

\begin{abstract}
Isotopic data, i.e. $\delta^{13} \mathrm{C}$ and $\delta^{18} \mathrm{O}$ including ${ }^{86} \mathrm{Sr} /{ }^{87} \mathrm{Sr}$, are the fundamental data to characterize geochemically magnesite mineralizations. Other geochemical data, e.g. chemical data, REE and fluid chemistry, are supplementary characteristics for genetic models. The geological setting and the origin of magnesium are relevant to classify magnesites genetically. The $\delta^{13} \mathrm{C}-\delta^{18} \mathrm{O}$ - diagrams of magnesite and siderite are significantly different. Stratabound magnesite is dominated by the isotopic signature of carbonate sediments, while siderites from occurrences with economic importance preferably show light carbon isotope like the ultramafic-hosted vein type mineralization. The $\delta^{18} \mathrm{O}$ original values of sparry magnesites are strongly influenced by burial and grade of metasomatism. Thus, the origin of sparry magnesite hosted by metasediments is to be considered as a sedimentary enrichment influenced by diagenetic and metamorphic processes. An approach to the best genetic model of each magnesite deposit needs the synopsis of all geological facts and geochemical data.
\end{abstract}

Key words: carbon and oxygen isotopes, magnesite, siderite, carbonate rock

\section{Introduction}

Magnesite is a rare rock forming mineral occurring in different marine and non-marine geological settings due to the geochemical relations of silicon, iron and calcium. However, magnesite deposits have been formed since the Archean either as carbonated ultramafic rocks or as sedimentary beds. Moreover, major magnesite deposits occur in the Precambrian, and thick magnesitedominated sequences are unknown in the Phanerozoic (Abu-Jaber \& Kimberley 1992). Uncertainties concerning the genesis of ultramafic-hosted deposits are discussed by Abu-Jaber \& Kimberley (1992). The formation of sparry magnesite hosted by metasediment series has been under discussion for two centuries in Europe. Rumpf (1883) created the idea of hydrothermal Mg-rich fluids replacing unconsolidated carbonate sediments, and Koch (1893) assumed that consolidated carbonates are transformed into sparry magnesite. The sedimentary precipitation of magnesite and dolomite appeared still unlikely. Then, both carbonate minerals could not been synthetisized. Although the physicochemical conditions are now well known
(Usdowski 1994), controversial models coexist: a sedimentary and a hydrothermal context (Pohl \& Siegl 1986, Möller (ed.) 1989). The sedimentary conception is based on sedimentary-diagenetic up to anchimetamorphic processes to form sparry magnesite. Pohl \& Siegl (1986) concluded that the majority of Veitsch type magnesite is probably of a sedimentarydiagenetic origin.

The essential question is the origin of magnesium. Principally, two main sources are Mg-rich magmatic rocks, i.e ultramafics, and magnesium originating from seawater that precipitates as carbonates or may be enriched by evaporitic processes. Heavy isotope mass spectrometry is perhaps a new geochemical tool to give us information about magnesium isotopes.

Classification of magnesite deposits traditionally has been based on "types" based from Middle European localities (Pohl \& Siegl 1986). Generally, the use of type deposits is unsatisfactory. Equally, the usage of cristallinity is problematic to classify magnesite deposits, distinguishing macroscopically into cryptocrystalline, fine-grained and coarse-crystalline (sparry) magnesites (Abu-Jaber \& Kimberley 1992). 
Nevertheless, the grain size is an important mineralogical property and the transition from type localities to new terms should be favoured.

The classification of magnesite deposits into two main groups - ultramafic-associated and stratabound magnesite deposits - is obvious considering the geological setting (Abu-Jaber \& Kimberley 1992). The classification presented in Table 1 combines this concept with magnesium. Table 1 contains the terms used in this paper.

Table 1: Classification of magnesite occurrences

\begin{tabular}{|c|c|}
\hline Setting & Corresponding "type" term or example \\
\hline \multicolumn{2}{|l|}{ Magnesites ultramafic-associated } \\
\hline \multicolumn{2}{|l|}{ Surface and surface near to hydrothermal mineralization } \\
\hline \multicolumn{2}{|l|}{ Concretions (soil weathering) } \\
\hline Stratiform mineralization (lacustrine/evaporititic) & Bela Stena.type \\
\hline $\begin{array}{l}\text { Vein-typ (with transition to } \mathrm{CO}_{2} \text { and fluid from deep } \\
\text { sources) }\end{array}$ & Kraubath type \\
\hline Vein-type in submarine environment & Possible ? \\
\hline \multicolumn{2}{|l|}{ Metamorphic ophiolitic environment } \\
\hline Mineralization in greenschist facies & Hochfilzen, Breitenau \\
\hline Mineralizations in amphibolite facies & Greiner type \\
\hline \multicolumn{2}{|c|}{ Magnesites stratabound in sedimentary environment (non ultramafic-associated) } \\
\hline Mineralization in terrestriale environment & Redbed type (Alpine Permian) \\
\hline \multicolumn{2}{|l|}{ Mineralization in playa/sabkha environment } \\
\hline Modern and Quaternary & Caroorong L., Sebkha el Melah \\
\hline Ancient & Barton Farm, Adelaide Syncline \\
\hline Association with evaporites & Kaswasser (Hall) type \\
\hline Mineralization in marine-sedimentary rock series. & Sabka el Melah \\
\hline Mineralization in metasediment rock series & Veitsch type \\
\hline \multicolumn{2}{|c|}{ Uneconomic occurrences in hydrothermal ore mineralizations } \\
\hline
\end{tabular}

\section{Geochemical characterization}

Different geochemical methods have been applied to find the proper genetic model with the aid of the minor element Fe and trace elements, e.g. Mn, Ni, B, REE, or with the fluid chemistry, eg, $\mathrm{Na}, \mathrm{Cl}, \mathrm{Br}$. The Fe-content magnesites are primarily connected to the origin of $\mathrm{Mg}$. The geochemical average of ultramafic and mafic rocks is around $9 \% \mathrm{Fe}$, while seawater is extremely poor on Fe. Generally, magnesites associated with ultramafics are characterized by higher Fe-content (reported up to
$5 \% \mathrm{Fe}$, Dulski \& Morteani 1989) than those from sedimentary environments ( $\leq 1 \% \mathrm{Fe}$ ). Regarding the purity of $\mathrm{Fe}$, the exceptions are surface-near mineralizations hosted by ultramafics due to the oxidation of iron Otherwise, diagenetically formed magnesites (Beran et al. 1989) and sparry magnesites of some metamorphic deposits show elevated iron contents, e.g 2.9\% Fe Veitsch, 2.0 to 2,35 Fe Breitenau (Eastern Alps, Austria) (Pohl \& Siegl 1986). The Fe/ $\mathrm{Mn}$ ratio in magnesite is commonly correlated due to the redox behaviour of both metals (Möller 1982). 
The geochemistry of trace elements in magnesite was studied by Möller (1989). Geochemical characterization of magnesites displays $\mathrm{Cr}, \mathrm{Ni}$ and $\mathrm{Cu}$ in ultramafic environment $\mathrm{Cr}, \mathrm{Ni}$ and $\mathrm{Cu}, \mathrm{B}$ and $\mathrm{Ti}$ in marine-evaporitic environment and $\mathrm{Ni}$ and $\mathrm{Cu}$ in lacustrine environment. $\mathrm{Hg}$, $\mathrm{As}$ and $\mathrm{Sb}$ are reported in magnesite from veins in ultramafic rocks (Abu-Jaber \& Kimberly 1992). However, the substitution of these trace elements into the lattice of magnesite is limited and most of the elements mentioned above are impurities.

REE patterns were favoured as proper tools to solve the problem of formation of sparry magnesite and of the origin of Mg. Unfortunately, the first samples are taken from deposits of the Entachen-Hochfilzen type hosted by Old Paleozoic rock series in the Eastern Alps/ Austria. (Morteani et al. 1982). The mostly fine-grained magnesites of these deposits show significantly sedimentary texture that excludes each model of metamorphogenic, metasomatic processes (Schulz and Vavtar 1989). Sparry magnesite of the Veitsch type was later investigated by Kiesel et al. (1990) and Kralik (1993). The REE-patterns are interpreted as the takeover of the REE distribution from pre-existing marine carbonate rocks caused by $\mathrm{Mg}$-bearing metamorphic fluids. Kralik and Kiesel (1994) suggested that magnesium originates from ultramafic rocks. However, seawater and ultramafic rocks are poor on REE, and only very low amounts of the heavy REE group may be substituted into the magnesite lattice (Möller 1989). The complete separation of the magnesite rock from impurities, e.g. dolomite, silicates and heavy minerals, remains uncertain, as reported by Tufar (2001). The incorporation of $\mathrm{Eu}^{2+}$ into the magnesite lattice is unlikely, no less than the incorporation of $\mathrm{Sr}^{2+}$ due to the equal size of ionic radii. Indeed, positive anomalism of $\mathrm{Eu}^{2+}$ is rarely reported from magnesite, e.g from secondary hydrothermal mobilization products, like magnesite veins or singular deposits, e.g. Radenthein (Austria) (Tufar et al. 1989).

Fluid chemistry is another important contribution to the geochemical characteristics of magnesite (Prochaska 2001). Nearly identical Na/Br- $\mathrm{Cl} / \mathrm{Br}$ data are reported from magnesite and siderite from selected occurrences in the Eastern Alps, indicating an evaporitic trend of halogenide fractionation. Besides, metamorphogenic fluids from the Alpine saliniferous would leach of iron from silicate rocks due to the long distance of fluid flow. Contrary, the Alpine saliniferous really has influenced the formation of siderite and other hydrothermal mineralizations of Alpidic age.

\section{Carbon and oxygen isotopes in magnesite}

Data of isotopes of carbon and oxygen give fundamental information regarding carbonates, e.g. origin of carbon and oxygen in fluids, mixing of fluids, secondary processes, biogenic activity, temperature range of fluids. The $\delta^{13} \mathrm{C}-\delta^{18} \mathrm{O}$ - diagram of magnesite (Fig.1) shows affinity to the diagram of calcite and dolomite (Fig. 2). The isotope data of deposits of sparry magnesite hosted by metasediments correspond with marine carbonate rocks derived $\left(\delta^{13} \mathrm{C}\right.$ at $0 \%$ and $\delta^{18} \mathrm{O}<$ $10 \%$. (PDB). There is no significant isotopic difference between sparry magnesite and their supposed precursor rocks. The shifting to lower $\delta^{18} \mathrm{O}(\mathrm{PD})$ - values is typical for magnesite deposits influenced by diagenetic and metamorphic processes. At high-grade metamorphism, just above the amphibolite facies, the isotopic composition approaches that of magmatic carbonates, i.e. carbonatites.

The carbon isotopes of magnesite depend among others on the $\delta^{13} \mathrm{C}$ values of coeval seawater and its carbonate rocks, evaporation, $\mathrm{CO}_{2}$-carbon from microbial fermentation processes, anaerobic decomposition of organic matter, thermal decomposition of carbonates ( \pm organic matter), $\mathrm{CO}_{2}$ produced by metamorphic and magmatic processes or combination of each above.

\section{Magnesite associated with Ultramafics}

Crypto/micro-crystalline, white-coloured magnesites occur in concretions in the soil or sediments immediately overlaying or adjacent to ultramafic rocks, and in strings and veins or stock works in the ultramafic rock bodies. Magnesite is formed by meteoric water at or near surface temperatures. Precipitation occurs also by percolating at low to moderate temperature from hydrothermal fluids in deeper horizons. Cryptocrystalline magnesite is hosted mostly in veins in ultramafic rock bodies is isotopically lighter, mostly $\delta^{13} \mathrm{C}$ -8 to $-20 \%$, maximum -9 to $-12 \%$, explained by a mixture of oxidized organic carbon and dissolved marine carbonates. Heavier $\delta^{13} \mathrm{C}$ values (-7 to $-9 \%$ ) in surface concretions and veinlets are influenced by atmospheric $\mathrm{CO}_{2}$-carbon (Kralik et al. 1989). New studies e.g. 
magnesite from the former Yugolavia (Fallick et al. 1991) and from western Turkey (Zedef al. 2000) show a $\delta^{13} \mathrm{C}$ range from +4 to $-15 \%$ (Fig. 1 ). Three sources of $\delta^{13} \mathrm{C}$ are described: i) atmospheric $\mathrm{CO}_{2}(\sim-7 \%$ ) at low temperature, ii) $\mathrm{CO}_{2}$ from decarboxylation of organic sediments $\left(-15 \%\right.$ ) at moderate temperature, iii) $\mathrm{CO}_{2}$ from thermal decomposition of limestone (-3\%o) at high temperature (Zedef et al. 2000). The vein deposit in Oshve/Bosnia associated with a dacite dike displays exceptionally deviating isotope data: $\delta^{13} \mathrm{C}+3 \%$ and $\delta^{18} \mathrm{O}$ $+19 \%$ o from vein-type deposits. An example of a complex fluid system showing wide variations of $\mathrm{C}$ and $\mathrm{O}$ isotopes is presented in Fig. 1 by the magnesite of the Rai-Iz Massif (former USSR). The isotope patterns are explained by the circulation of hydrothermal, probably metamorphic fluids (Kralik et al.. 1989).

Submarine-ultramafic magnesite mineralizations of magnesite are so far unknown. However, $\mathrm{Mg}$-calcite and aragonite are reported in veins in serpentinites at the newly discovered peridotitic-hosted City Vent field $\left(30^{\circ}\right.$ N, Middle Atlantic Rift). The carbonates have precipitated form 50up to $200^{\circ} \mathrm{C}$ (Boschi et al. 2002). The carbonates display values of $\delta^{13} \mathrm{C}-1$ to $-6 \%$ o (VPDB) and $\delta^{18} \mathrm{O}-20$ to $-7 \%$ (VPDB) deviating from vein magnesites formed by meteoric water in continental ultramafics.

The origin of magnesium from adjacent ultramafic complexes is evident also in sediments of lacustrine/ marine evaporitic environments since the Archean age, e.g. Barton Farm / Zimbabwe. Other examples of stratiform deposits are Bela Stena / Serbia, Servia basin / Greece, Adelaide Syncline / Australia. These magnesites have $\delta^{13} \mathrm{C}$ values ranging from +2 to $+10 \%$, explained as contribution of emanating volcanic $\mathrm{CO}_{2}$, equilibrium between $\mathrm{CH}_{4}$ and $\mathrm{CO}_{2}$ or anaerobic fermentation (Kralik et al. 1989). The extreme heavy $\delta^{13} \mathrm{C}$ values up to $+10 \%$ o from Servia are explained as anaerobic fermentation in underlying lignite seams (Kralik et al. 1989). Diagenetic processes deplete the oxygen in the isotope composition. Magnesite from recent lake sediments in the western Turkey, Lake Salda, reveal similar C-and $\mathrm{O}$ - isotopes as the magnesite from Bela Stena / Serbia (Zedef et al. 2000).

Magnesite occurring in ophiolithic environment corresponds in their isotopes with the associated carbonate rocks. Economically unimportant occurrences described, e.g. from the Erzwies/Rauris, Tauern Window
/ Austria (Reden 1991) or from the Rechnitz Window / Schlaining, Austria (Nawaratne 1989). Both localities are hosted by the greenschist facies. The isotope characteristic of the amphibolite facies, i.e. near carbonatites, is realized in the deposits of Greiner (Ochsner) type /Zillertal Alps, Austria. The genesis of this magnesite deposit is interpreted by the reaction of $\mathrm{Mg}$-silicates with a $\mathrm{CO}_{2}-$ rich aqueous phase $\left(\mathrm{CO}_{2}-\right.$ metasomatose) (Dulski and Morteani 1989). A model of metamorphic surface mineralization would not easily confirm this magnesite type. Abu-Jaber and Kimberley (1992) classified three other deposits as of the "massive type" (Greiner type). This type has distinct isotopic markers, and isotope data were not considered to classify them.

\section{Stratabound magnesites in sedimentary environment (non ultramafic-associated)}

Fine-grained magnesites in sedimentary environment are stratiform occurrences formed either under sabkha or playa conditions. Recent occurrences are e.g. Coorong Laguna/ near Adelaide, Australia. The carbonates from Coorong show the normal marine range of $\delta^{13} \mathrm{C}(0,3$ to $3,5 \%)$. The Quaternary magnesites and huntites from Sebkha el Mela / Tunisia show light carbon $\left(\delta^{13} \mathrm{C}\right.$ average $-3 \%$ ), indicating the influence of non marine solutions (Kralik et al. 1989)

Crypto- to fine -grained sedimentary and diagenetically mobilized blocky magnesites are common in the PermianScythian of the Alps (Niedermayer et al. 1989). In the Upper Permian Gröden Formation, magnesites in terrigenous environments are isotopically different from magnesites of the salt- and/or gypsum- and anhydrite-bearing occurrences in the Upper Permian Alpine Haselgebirge Formation. The $\delta^{18} \mathrm{O}$-values are higher in the terrigeneous redbed facies, and the lowest $\delta^{13} \mathrm{C}$ value is $-10 \%$ o. The $\delta^{13} \mathrm{C}$ - and $\delta^{18} \mathrm{O}$-values of fine-grained magnesite in the Gröden Formation indicate that they were formed at surface temperature in a freshwater environment and underwent a shallow burial (Spöttl \&Burns 1994).

Concretions (not marked in Fig, 1) are in the range of $\delta^{13} \mathrm{C}-12$ to $+0,3 \%$ o. The similar isotope field of the Upper Permian/Sythian evaporitic facies is shifted to lower $\delta^{18} \mathrm{O}$-values (Fig.1). The depletion of carbon isotope is interpreted as remnant of a fresh water episode (Niedermayer et al. 1989). The C-O isotope values of sparry magnesites hosted by Anisian bituminous 
dolomite, i.e. Kaswasser-type (e.g. Kaswassergraben, Hall in Tyrol, Diegrub, Zumpanell/Ortler Triassic) from a cluster around $\delta^{13} \mathrm{C}+2,2$ and $\delta^{18} \mathrm{O}+23$.

\section{Magnesite in metasediments}

The fine-grained magnesites of the Devonian Entachen-Hochfilzen type (Northern Tyrol) show a similar isotope pattern to the above-mentioned PermianScythian magnesites in saliniferous environment. The lowest $\delta^{13} \mathrm{C}$ value is $-15 \%$. These data correspond to the descriptions of typically sedimentary textures (Schulz and Vavtar 1989). Magnesite from Breitenau/ Styria shows nearly identical average $\delta^{18} \mathrm{O}$ values with the highest $\delta^{18} \mathrm{O}$ value of the magnesite samples from Entachen-Hochfilzen/Tyrol.

The $\delta^{13} \mathrm{C}$ values from typical sparry magnesite deposits are in the range of -6 to $+7 \%$ (average at $0 \%$ ). Metamorphism of the amphibolite facies causes a depletion of carbon isotopes. Increasing metamorphism changes the $\delta^{13} \mathrm{C}$ into lighter carbon, e.g. magnesites from Tux, Radenthein or Rabenwald (Eastern Alps). Sparry magnesite of ophiolites in the greenschist facies displays $\delta^{13} \mathrm{C}$ values in the range of seawater-derived carbonates. The $\delta^{18} \mathrm{O}$ values increase significantly with the grade of metamorphism (Kralik et al. 1989) (Table 2).

There are some reasons why the Veitsch type is hydrothermal - epigenetic:

i) Sedimentary, diagenetic and weakly metamorphic mineralizations of fine-grained to sparry magnesites occur. There is no reason that sparry magnesite deposits from the Veitsch type are to be classified as epigenetic deposits originating from metamorphogenic fluids

ii) The isotope patterns (Fig. 1 and 2) show clearly that the oxygen isotopes of sparry magnesite correspond to the path of diagenetic and metamorphic reactions for sedimentary calcite and dolomite.

iii) The scattering of ${ }^{86} \mathrm{Sr} /{ }^{87} \mathrm{Sr}$ ratios are characteristic for local activities of metamorphic fluids, and do not correspond to assumptions of a long distance transport of magnesium (Frimmel \& Niedermayer 1991). Magnesites from marine sedimentary and weakly metamorphosed occurrences tend to the coeval seawater marker.

iv) Interpretations of halogenide geochemical data are not definitive. The halogenide patterns can originate from epigenetic fluids as well as from remnants of a previous sedimentary environment. The $\mathrm{Cl} / \mathrm{Br}$ ratio of seawater is constant so far as known in Phanerozoic, and is not a time marker as sulfate sulfur.

Magnesite beds in sabkha/playa environment are extensively mined, especially large and giant deposits occurring during the Precambrian-Cambrian-transition, in the Upper Proterozoic, e.g. Satka/southern Ural, in the early Precambrian deposits in northwest China in the Liaoning Province, e.g Ta-shi-chiao (Dashiqiao) or

Table 2: $\delta^{18} \mathrm{O}$ average values of sparry magnesites and the grade of metamorphism in the Alps.

\begin{tabular}{llccl}
\hline Deposit(s) & age & $\mathrm{n}$ & $\delta^{13} \mathrm{C}(\mathrm{PDB})$ & grade of metamorphism \\
\hline Redbed-type & Permian & 3 & 24,0 & late diagenetic \\
Kaswasser-type & Triassic & 7 & 23,0 & late diagenetic \\
Breitenau & Upper Silurian & 4 & 17,8 & lower greenschist facies \\
Entachen -Hochfilzen & Silurian/Devonian & 5 & 18,6 & lower greenschist facies \\
Veitsch-type & Carbonian & 6 & 15,6 & greenschist fascies \\
Tux-Lannersbach & Silurian/Devonian & 15 & 13,1 & upper greenschist facies (?) \\
Radenthein & unknown & 2 & 9,9 & amphibolite facies \\
Ochsner & unknown & 8 & 6,9 & amphibolite facies \\
\hline
\end{tabular}




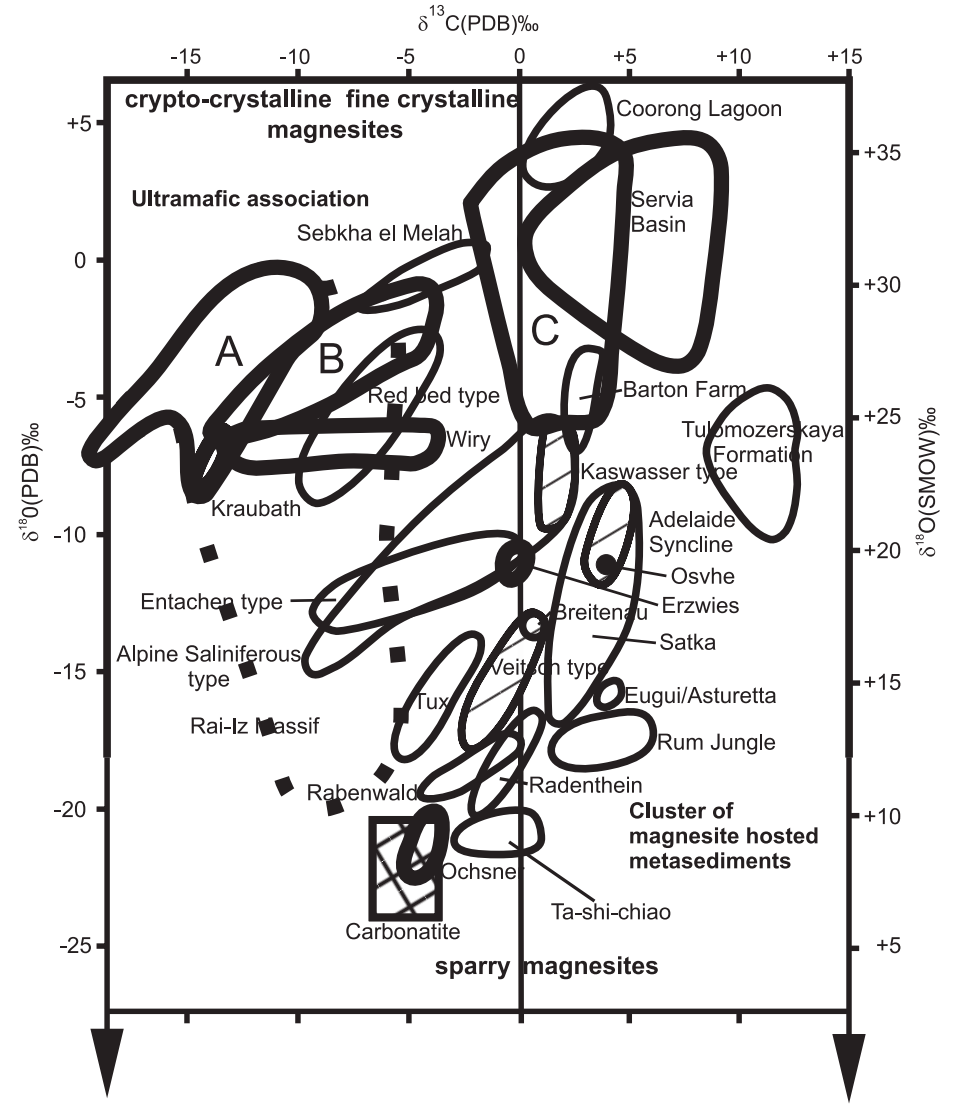

Fig. 1. $\delta^{13} \mathrm{C}-\delta^{18} \mathrm{O}$ diagram of selected magnesite occurrences (Kralik et. al. 1989, Schroll 1997. Schroll et. al. 1999) supplemented by further data (Fallick et al. 1991, Zedef et al. 2000, Melzhik et al. 2001). The fields of ultramafic-associated deposits are set off against the fields of stratabound non ultramafic-associated deposits. The data set of vein and stockwork deposits consisting of data from the Alps, Carpathians, Dinarides, Greece, Turkey and California/USA (Kralik et. al. 198) is compared with data from Dinarides and western Turkey (Fallick et al. 1991, Zedef et al. 2000). The stratiform sabkha/playa deposits and the cluster of sparry magnesite in metasediments enclose the deposits of the Eastern Alps as well as other deposits of different geological age as mentioned in the text. Abbreviations: A, B, C (modern lacustrine and stratiform magnesites in the Dinarides and western Turkey), TUX Tux-Lanerbach, RAB Rabenwald, RAD, Radenthein.

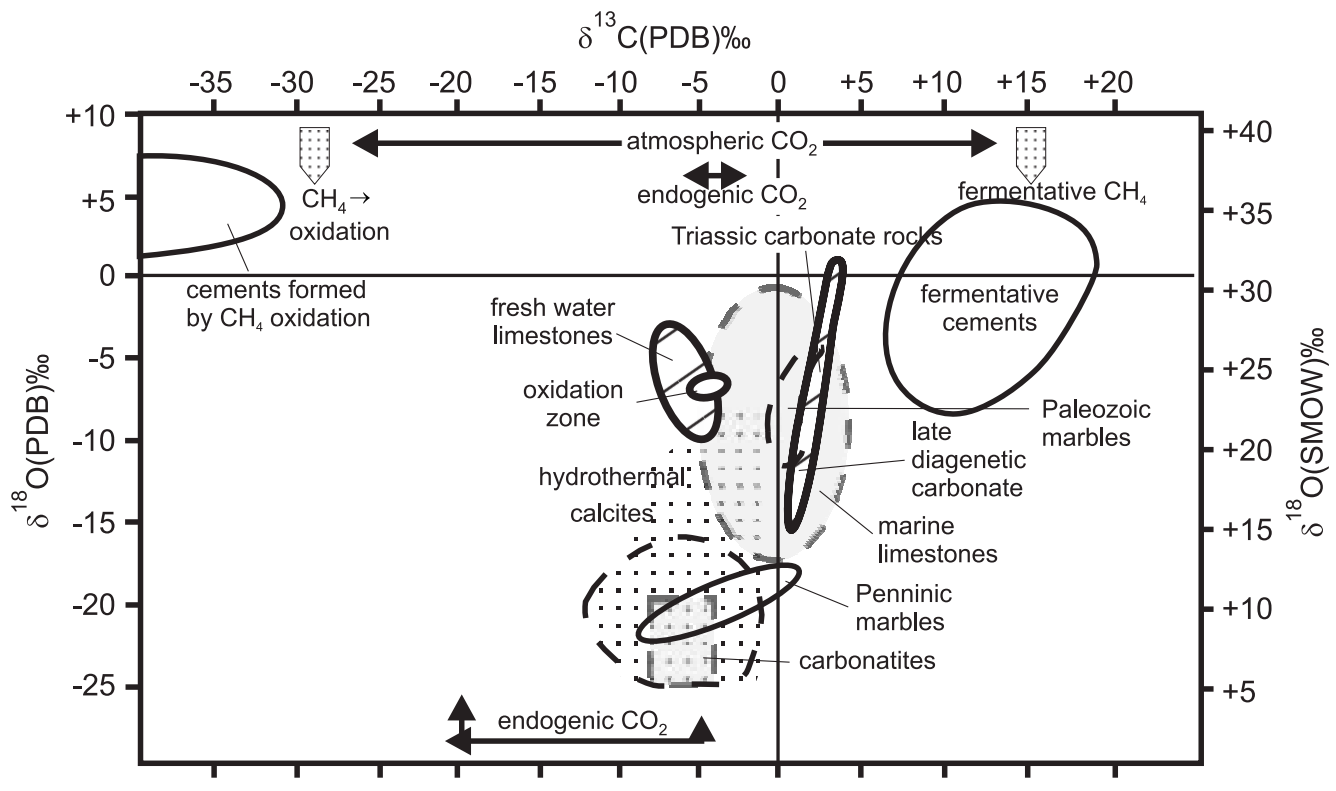

Fig. 2. $\delta{ }^{13} \mathrm{C}-\delta^{18} \mathrm{O}$ diagram of selected calcite (dolomite) rocks and minerals (Schroll 1997) 


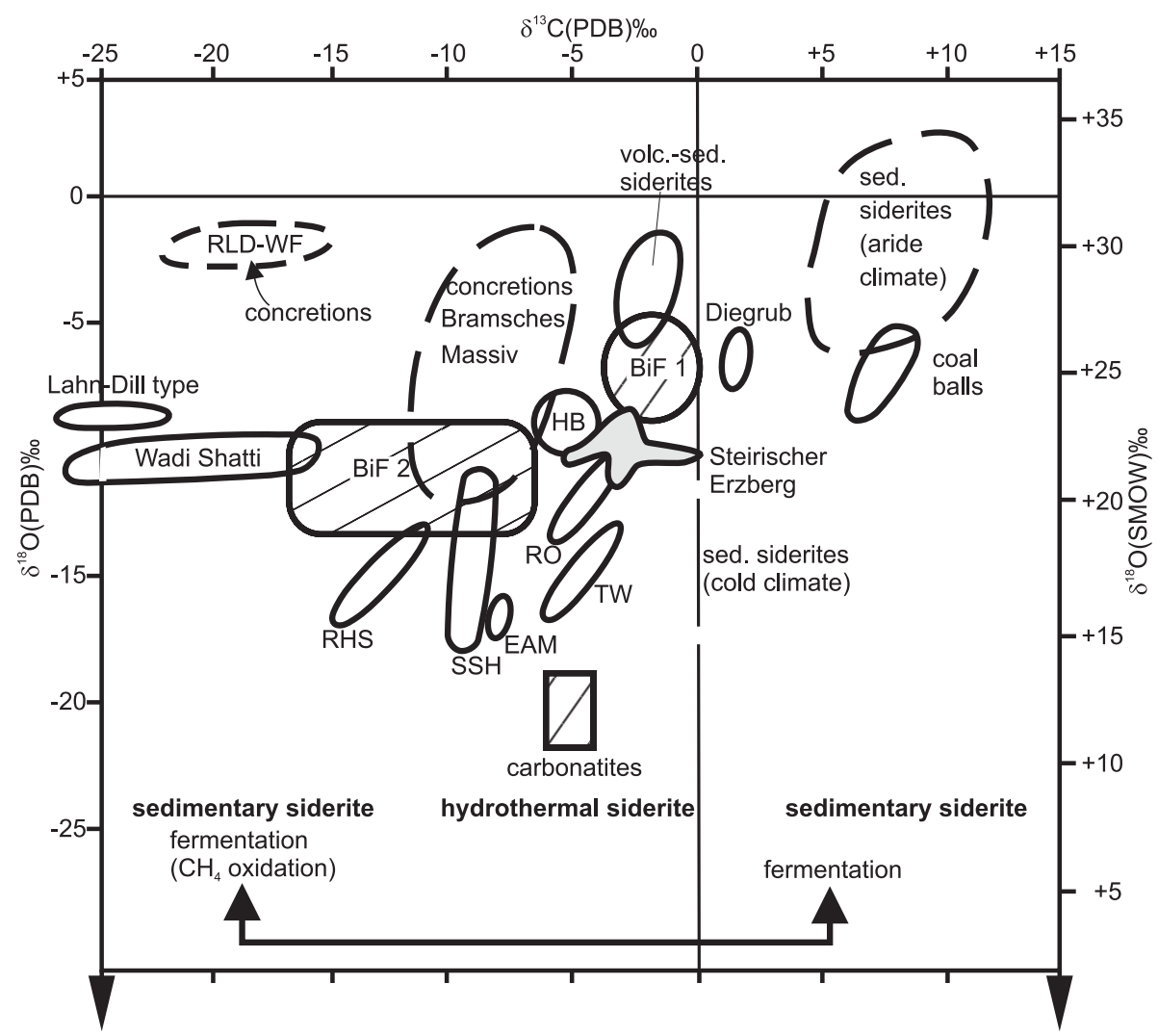

Fig. 3. $\delta{ }^{13} \mathrm{C}-\delta{ }^{18} \mathrm{O}$ diagram of selected siderites (data from Zartmann \& Jungmann, 1984, Schroll et al. 1986, Mozley \& Wersin 1992, Schroll 1997, Schroll et al. 1999). Abbreviations: BIF 1 Banded ironformation Biwabik, Minnesota, BIF 1 Banded ironformation Biwabik, Minnesota, metamorphic, magnetite-bearing, EAM magnetitebearing occurrences in the Eastern Alps, HB Hüttenberg, Austria, RHS vein siderites, Rheinisches Schiefergebirge, Germany, RLD-WF siderite from concretions, RheinlandWestfahlen, Germany, RO Rošnava, Westen Carpathians, SSH Sunshine mine and other vein siderites (USA), TW vein siderite from the Tauern window, Eastern Alps.

in the Archean beds, e.g Sebawakian Group Que Que schist belt/Zimbabwe. The $\delta^{13} \mathrm{C}$ values are overwhelmingly heavy. Extremely heavy $\delta^{13} \mathrm{C}+7$ to $+12 \%$ is reported from Paleoproterozic ( $2 \mathrm{Ga})$ magnesite beds within the Tulomozerskaya Formation, NW Fennoscandian shield. The extremely high $\delta^{13} \mathrm{C}$ values reflect a combined contribution of global reservoir $\left(\delta^{13} \mathrm{C}+5 \%\right.$ ) and local carbon sources $\left(\delta^{13} \mathrm{C}\right.$ up $+12 \%$ ), The $\delta^{13} \mathrm{C}$-rich global reservoir is related to the perturbation of the carbon cycle at $2,0 \mathrm{Ga}$, and the local enhancement $\delta^{13} \mathrm{C}$ is caused by evaporation and high bioactivity ( Melezhik et al. 2001).

\section{Magnesites originating from epigenetic- hydrothermal processes}

Occurrences of magnesite are described in hydrothermal ore mineralizations. Magnesium is derived from ultramafic and sedimentary (dolomite) host rocks. For instances, ferrous magnesite is reported from the Mount Bischoff cassiterit sulphide skarn deposit/ western Tasmania occurring in a dolomite unit. The magnesite reflects the lowering of the silica activity in the fluid when it reacted with dolomite (Halley \& Walshe 1995). 


\section{Comparison with siderite}

The comparison of the $\delta^{13} \mathrm{C}-\delta^{18} \mathrm{O}$ - diagram of magnesites (Fig. 1) with the analogous siderite diagram contributes to understand similarities and differences of their genesis (Fig. 3). Siderites and magnesites from diagenetic incrustations and geodes reveal no significant difference in the isotopic distribution. Sedimentary siderites are influenced by bacteriogenic fermentation processes. The $\delta^{13} \mathrm{C}-\delta^{18} \mathrm{O}$ fields of marine-sedimentary and continental-sedimentary siderites are partly overlapping. Climatic conditions strongly determine the $\delta^{13} \mathrm{C}-\delta^{18} \mathrm{O}$ data of continental sedimentary siderites. Heavy oxygen (SMOW) indicates the formation in arid climate, while lighter oxygen is found in cold-humid climate. Apparently, diagenetic processes influence the $\delta^{18} \mathrm{O}$ - distribution of siderites less than the distribution of magnesites.

Localities are very rare where continuous crystalline solutions of $\mathrm{FeCO}_{3}$ and $\mathrm{MgCO}_{3}$ are described, e.g. Diegrub/Salzburg, Austria in an evaporitic environment in the Eastern Alps as above mentioned (Beran, 1978). In the western Northern Graywacke zone in the Eastern Alps, occurrences of $\mathrm{Mg}$-rich siderite and ferrous magnesite in hydrothermal mineralizations are linked with the preference of metabasites in this terrain. Contrary to sparry magnesite, siderites are preferably in the range of light carbon. Siderites of hydrothermal origin dominate in the $\delta^{13} \mathrm{C}$ range -5 to $-15 \%$. Volcanogenic $\mathrm{CO}_{2}$ is indicated by $\delta^{13} \mathrm{C}$ valued at $-5 \%$ o, e.g. siderite of submarine mineralization in Red Sea. Siderites of veins display a characteristic isotope variation, mainly of oxygen, explained by fluid mixing. Siderites deposed by metamorphogenic-hydrothermal fluids, e.g. in the Tauern gold veins, are characterized by light carbon around $\delta^{13} \mathrm{C}-10 \%$ as well metasomatic siderites in carbonate environment, e,g, Hüttenberg. The available data set of isotopes scarcely shows siderite formed by replacement in carbonate rocks in the isotope range of marine carbonates. Thus, fact and data are not correspondent to the model of epigenetic metamorphogenic fluids.

A fundamental difference between magnesite and siderite is the thermal stability of magnesite up to $600^{\circ} \mathrm{C}$. High grade metamorphism forms magnetite in siderite mineralization. Fig. 3 shows no siderite in the field of carbonatites.
Redlich (1904) suggested a genetic link between Veitsch-type magnesites deposits and the siderite deposits in the Eastern Alps. This model for the Veitsch type implied a passage of mineralizing fluids from the depth through the tectonically superimposed strata. This model comes from the past idea that all ore deposits in the Eastern Alps should be formed by one event in a late stage of the Alpine orogeny. The different origin of magnesium and iron is reported for instances for the giant stratabound deposits hosted by Riphean carbonate rocks in the western Ural, the magnesite deposit Satka and the siderite deposit Bakal. New investigations (Ellmies et al. 1999) result in the model, that the magnesite is formed by the reflux of early diagenetic Mg-rich brines being responsible for selective replacements of brecciated dolomite. In contrary, the siderite originates from $\mathrm{Fe}$-bearing fluids, were probably generated by low-grade metamorphic devolatilization from underlying argillites. The fluid flows were focussed by overlaying coarse clastic rocks, causing the metasomatic formation of large siderite ore bodies in carbonate rocks.

\section{Conclusion}

Carbon and oxygen isotopes of magnesites correspond to the classification of magnesite deposits in ultramafic-associated and non-ultramafic-associated deposits. Only the stratabound deposits of the both groups show overlapping. The carbon isotope divides the magnesite in three field depleted carbon isotopes in magnesites from ultramafic associations in near surface and vein type settings, carbon isotopes around $0 \%$ in saliniferous sedimentary environment and heavy carbon in lacustrine and marine evaporitic environments. The carbon isotopes are important markers in determining the source of carbon. The oxygen isotope data reflects the isotopic signature of water in which the magnesite precipitates and the temperature in which precipitation occurs. A increase of temperature during diagenetic and metamorphic processes changes the isotopic composition during diagenetic and metamorphic fluid reactions comparable with other carbonate rocks. Thus, the genetic aspects of sparry magnesite deposits in metasediments series correspond to the model of sedimentary origin.

The sedimentary magnesite model of magnesite deposits in metabasites is confirmed by comparison of 
the $\delta^{13} \mathrm{C}$ and $\delta^{18} \mathrm{O}$ distribution between magnesite and siderite. Epigenetic siderites in veins and replacements display significantly depleted carbon isotopes, contrary to the magnesite in metasediment series ("Veitsch type"). Geochemical properties and considerations support the statement that stratabound magnesites are scarcely linked with siderite mineralizations.

Investigations of magnesite deposits may not be restricted to local occurrences. Only a global study, including isotope data, would advance to better understanding.

\section{References}

Abu- Jaber, N.S. \& Kimberley, M.M., 1992. Origin of ultramafichosted vein magnesite deposits, Ore Geology Reviews , 7, 155-191.

Beran, A. 1978. Die Bestimmung der Zusammensetzung von Dolomit, Ankerit and Magnesit-Siderit, Mischkristallen mit Hilfe von Reflexionsmessungen. Neues Jahrbuch. Mineralog. Monatshefte 1978, 559-565.

Boschi, C., Frueh-Green, \& Kelley, D.S., 2002. Serpentinization and carbonate precipitation at Conference, Davos, pp A 24.

Dulski, P. \& Morteani, G., 1989. Magnesite formation by $\mathrm{CO}_{2}$ metasomtism duringregional metamorpgism of the ultrabasic rock of the Ochsner serpentinite (Zillertaler Alpen, Tyrol, Austria). Monograph Ser. Mineral Deposits, 28, 95-104.

Fallick. A.E., Ilich, M. \& Russel, M.J., 1991.. A stable isotope study of the magnesite deposits associated with the Alpinetype ultramafic rocks of Yugoslavia. Econ. Geol.. 86, 847861.

Ellmies, R., Voigtldnder, K,. Germann, K., Krupenin, M.T. \& Möller, P., 1999. Origin of giant stratabound deposits of magnesite and siderite in Riphean carbonate rocks of the Bashkir mega-anticline. Geol. Rundschau, 8, 589-602.

Frimmel, H. \& Niedermayr, G, 1991. Strontium isotopes in magnesites from Permian and Triassic strata, Eastern Alps. Appl. Geochem., 6, 89-98.

Halley, S.W. \& Walshe, J.L., 1995. A re-examination of the Mount Bischoff cassiterite sulphide skarn, western Tasmania. Econ.Geol. 90, 1676-1693.

Kiesl, W., Koeberl, C. \& Körner, W., 1990. Geochemistry and dolomites at the Oberndorf/Laming (Austria) deposit and its implications for their origin. Geol. Rundschau, 79, 327-335.

Koch, M., 1893. Mittheilung über einen Fundpunkt von Untercarbon - Fauna in der Grauwackenzone der Nordalpen. Zeitschr. Deutsche Geol Ges. 45, 294-298.

Kralik, M., Ahron, P., Schroll, E. \& Zachmann, V. 1989. Carbon an oxygen isotope systematics of magnesites in magnesite formation. Monograph Ser. Mineral Deposits, 28. 207-224.

Kralik, C.,1993. Geochemische Untersuchungen an Magnesiten und Talken an den Lagerstdtten der Ostalpen. Doctor Thesis, Univ. Wien.
Melezhik, V.A., Fallick, A.E., Medvedev, P-V. \& Makarikhin, V.V., 2001. Paleoproterozoic magnesite: lithological and isotopic evidence for playa/sabkha environments, Sedimentology, 48, 379-397.

Möller, P. (ed.), 1989. Magnesites. Monograph Ser. Mineral Deposits 28, Gebr. Borntrdger, Berlin -Stuttgart.

Morteani, G-T., Schley., F. \& Möller, P., 1981: The formation of the magnesite deposits of the northern Grauwackenzone and of the Innsbrucker Quarzphyllite (Austria), deduced from rare earth fraction. Erzmetall, 34, 559-562.

Mozley, P. \& Wersin. P., 1982. Isotopic composition of siderite as an indicator of depositional environment. Geology, 51, 817-820.

Nawaratne, M. 1989. Geochemical, petrological and isotopic studies related to the genesis of antimony deposits in the Eastern Alps with special reference to the deposit Schlaining. Doctor thesis, Nat. wiss. Fak. Univ Wien.

Niedermayr, G., Beran, A. \& Brandstdtter, F., 1989. Diagenetic type magnesite in Permo-Scythian rocks of the Eastern Alps. Monograph Ser. Mineral Deposits, 28, 35-60, Gebr. Borntrdger, Berlin -Stuttgart.

Pohl, W. \& Siegl, W., 1986. Sediment-hosted magnesite deposits. In.: Wolf, K.H. (ed.) : Handbook of strata-bound and stratiform deposits Vol. 14, 223-310.

Prochaska, W. 2001. Magnesite mineralization in the Eastern Alps and the Carpathians. In: Pietrzyñsky, A. et al.; Mineral deposits at the beginning of the $21^{\text {st }}$ Century, 1017-1019, Balkema Publ., Lisse etc.

Reden, G., 1991. Beitrdge zur Geologie, Geophysik und Geochemie der Gesteine und Mineralisationen im Gebiete der Goldvorkommen in den Hohen Tauern (Badgastein-Kolm Saigurn-Heiligenblut) mit besonderer Berücksichtigung der Gangmineralisationen. Doctor Thesis, Nat. wiss. Fak. Univ, Wien.

Redlich, K.A., 1904. Über das Alter und die Entstehung einiger Erz- und Magnesitlagerstdtten der steirischen Alpen. Jahrbuch . Geol. Reichsanstalt (Wien), 53, 285-294.

Rumpf, J., 1873. Über krystallisierte Magnesite und ihre Lagerstdtten in den nordöstlichen Alpen. Verhandlungen Geol. Reichanstalt Wien), 312-315. 
Schroll, E., Dolezel, P. \& Papesch, W., 1986: Beitrag der C- und O- Isotopenanalyse zur Genese ostalpiner Sideritvorkommen. Mitteilungen. Österr. Geol. Ges., Bd. 78, 181-191.

Schroll, E. 1997. Abschnitt V: Geochemische und geochronologische Daten und Erlduterungen. In: Weber, L., Handbuch der Lagerstdtten der Erze und Industrieminerale und Energierohstoffe Österreichs, Archiv Lagerstdttenforsch., 19, 395-542, GBA Wien.

Schroll, E., Andraš, P. \& Chovan, M. 1999: A first attempt to geochemically compare ore deposits of the Western Carpathians and the Eastern Alps. Geological Carpathica, Special Issue, 50, 192-194, Bratislava.

Schulz, O. \& Vavdar, F., 1980. Genetic fabric interpretation of the magnesite deposit Weissenstein (Hochfilzen, Tyrol). Monograph Ser. Mineral Deposits, 28, 115-134.

Spöttl, C. \& Burns, S.Z., 1994. Magnesite diagenesis in redbeds: a case study from the Northern Calcareous Alps. Sedimentology 41, 543-565.

Tufar, W, Gieb, J., Schmidt, R., Möller, P., Pöhl, W., Riedler, H. \& Olsacher, A, 1989. Formation of magnesite in the Radenthein (Varinthia/Austria) type locality. Monograph Ser. Mineral Deposits, 28, 135-172.
Tufar. W., Siewers, U. \& Weber, Ch,. (2001): Die Spatmagnesit.Lagerstdtte Breitenau (Steier- mark), eine paldozoische Magnesit-Mineralisation.im Grazer Paldozoikum. Mitteilungen der Österr. Mineralog. Ges., 146, 292-294.

Tufar, W., Siewers, U, Weber, Ch . 2002: The Radenthein sparry magnesite deposit (Millstdtter Alpe, Carinthia, Austria,), a pre-alpine magnesite mineralization in the Middle Austroalpine Crystalline basement (,Altkristallin“) of the Eastern Alps. Geologica Carpathica, Special Issue 55 (Proceed. 17 $7^{\text {th }}$ Congress CBGA Bratislava), 192- 194.

Usdowski, E., 1994. Synthesis of dolomite and geochemical implications. In: Purser, B., Tucker, M. \& Zenger, D, (eds,); Dolomites; a volume in honour of Dolomieu. Spec. Publ. Internat. Assoc. Sedimentologists, 21, 345-360.

Zartmann. D. \& Jungmann R., 1984. C - und O Isotopenuntersuchungen an sideritischen Konkretionen des Rheinischen Schiefergebirges. Neues Jahrbuch. Geol. Paldont. Monatshefte, 689-708.

Zedef, V., Russel, M.J. \& Fallick, A.E., 2000. Genesis of vein stockwork and sedimentary magnesite and hydromagnesite deposits in the ultramafic terrain of southwestern Turkey; a stable isotope study. Econ. Geol.95, 429-445. 